\title{
Authentic Assesment of The Lesson Planning Accomplished by The Indonesian Language and Literary Teachers in Bogor Secondary Schools
}

\author{
Suhendra $^{*}$, Rina Rosdiana ${ }^{*}$, Stella Talitha ${ }^{*}$ \\ ${ }^{*}$ University of Pakuan, Bogor, Indonesia \\ Corresponding Author: suhendradada@yahoo.co.id
}

\begin{abstract}
Teachers are an significant element in the development of assessment instruments. Assessing is, therefore, one of the competencies that must be possessed by teachers . The teacher's understanding of the assessment can be reflected in the assessment presentation on the Lesson Plans (RPP). This study examines the preparation of authentic assessment of the even semester Lesson Plan in the Indonesian language curriculum at five high schools in Bogor. The applied method in this research is qualitatively descriptive research. The purpose of this study is to describe 1) the accuracy of the formulation of the problem with the basic competence and indicator, 2) the completeness of the assessment instrument, and 3) the selection of assessment type. The results showed that $90.9 \% \mathrm{BC}$ or indicator evaluation instrument is made while $9.1 \%$ is not made. This causes the teacher unable to know the level of students' understanding of the BC. Ninety percents $(90 \%)$ of instrument evaluation is less precise; while $10 \%$ of the evaluation instrument is less precise, less appropriate. Forty ( $40 \%$ ) of evaluation instruments are complete and $60 \%$ are incomplete (no scoring guidelines and answer keys). There are seven development forms of authentic assessment, namely performance appraisal, project appraisal, portfolio assessment, written assessment, attitude assessment, self-assessment, and product assessment. Here is an overview of the authentic assessment form used by teachers. $20 \%$ of all indicators are studied, in the form of performance appraisals, the type is the oral practice. Meanwhile, $80 \%$ is a written assessment, in the form of multiple choice test and description (short field and essay). This shows that most teachers do not take advantage of other forms of authentic assessment.
\end{abstract}

Keywords: authentic assessment, basic competencies, indicators.

\section{INTRODUCTION}

Assessment is an activity undertaken in assessing the sustainability of a plan or program. Assessment can be done within the range of the current activity or at the end of the program. The purpose of the assessment is to measure the achievement of an activity or program. Assessment is also unseparable from educational, teaching and learning, activiities in general. All these activities should always be followed or accompanied by assessment activities. It would be peculiar if there is a teaching activity conducted by a teacher in the classroom without being followed by an assessment. Without making an assessment, it is impossible to assess and report objective learning outcomes

It will be risky of evaluation activities are conducted only by relying on observation techniques alone. The element of assessment subjectivity is very essential. It is not uncommon that between what the eye sees, is observed, such as the behavior of student learning outcomes, does not reflect the actual circumstances or abilities. If this is the case, then there has been a mistake in giving consideration in interpreting the students' learning outcomes because the gained information is not reliable.

Assessment is a complex activity. Various factors are involved and must be taken into account in this activities, and not just basing themselves on the nature of common sense only. This is also because we are going to measure the ability or achievement of the students. This is an intangible character, and to measure it appropriate measuring tools are required.

It is clear that assessment should be conducted during and at the end of the activity. Similarly, the assessment activities on learning are arranged in the form of Learning Implementation Plan (RPP) and implementation activities assessment. The ability of teachers in making judgments will affect the achievement of basic competencies. For that reason, a study entitled "Authentic Assessment in Lesson Plans for Indonesian Language and Literature Teachers at Secondary Schools in Bogor" will be implemented. This study will reveal the development of an authentic assessment of the Lesson Plans by Indonesian language 
and linguistic teachers of the secondary schools in Bogor.

The formulation of the problem in this research will show: how is the appropriateness of authentic assessment instrument made by teachers in Bogor secondary school according to basic indicator and competence based on the 2013 Curriculum?

The objective of this study was to obtain an overview of the appropriateness of the assessment instruments made by teachers in secondary schools with the basic indicators and competencies in line with the 2013 Curriculum .

Here, the term judgments are synonymiously and interchangeably used with the term evaluation. The term judgment itself - which is frequently equated with the test - raises many different interpretations, some of which even refer to negative connotations. Assessment in the latter connotation is frequently seen as something frightening, unpleasant, especially for those who will be subjected to "action" judgments, be it named students, teachers, institutions or other parties. Assessment may be regarded as a violation of rights, or something that is restrictive of space, or vice versa.

To be able to provide accurate assessments , to asses the students 'ability to understand newspaper discourse, we need data about students' abilities in that regard. To obtain the necessary data, we need a measurement appraisal tool. Through measurement activities information about the level of student ability will be obtained. Measurement, therefore, is only part or tool of judgment only (Tuckman in Nurgiyantoro, 1988) and is always associated with quantitative data, for example in the form of student scores.

Quality control of education is essentially the quality control of human resources within the system. To know the extent to which the effectiveness of the control, we require information about the state of the learner whether a change occurs or not, the teacher functions or not or, whether the school supports the implementation of educational programsin such a way that the results can be optimally achieved. The purpose of authentic assessment is as follows.

a. The assessment planning of the learners should be conducted in accordance with the competencies to be achieved and based on the asssessment principles,

b. The assessment Implementation should be proffessionally open, educative, effective, efficient, and appropriate in accordance with the sociocultural context; and

c. The assessment report should be results, accountable, and informative.

There are seven forms of authentic assessment, namely: performance, project, portfolio, written, attitude, self-assessment, and product assessments

\section{RESEARCH METHODS}

This research was conducted by analyzing the Learning Implementation Plan in Indonesian Language and Literature Lesson in Bogor secondary school in. This research was conducted on the schedule of Indonesian Language and Literature in semester 5 starting April s.d. August 2017.

The method used in this research is qualitative research method. This research method selection is carried out on the reason to generate data or circumstances about the object under study correctly and supported data or empirical facts. Thus, the data on Learning Implementation plant development in Indonesian Language and Literature Lesson is a qualitative research.

In this study, researchers recorded all visible information, information extracted through interviews and documentation. The goal is to describe the behavior and activities of the community, in this case the community in the school environment so that social and cultural life can be expressed based on empirical facts found in the development of the Learning Implementation Plan on Indonesian Language and Literature Lessons in Bogor secondary schools .

Sources of data in this study are teachers who teach Indonesian Language and Literature Iesson in Bogor high schools. The research data collected in this research is information in the form of words, sentences, and paragraphs contained in the document. As Moleong discloses that in qualitative research the main data source is 'words' and 'action', the rest is additional data such as documents, and others. This means that the data used comes from written sources in the form of developing an authentic assessment of the Lesson Plans on Indonesian language and literature Lesson in secondary schools.

\section{RESULTS AND DISCUSSION}

Here is the data and discussion of authentic assessment. Presented data from nine schools with LIP approved by teachers at their schools.

\begin{tabular}{|l|l|l|l|l|l|l|l|l|}
\hline \multirow{2}{*}{ BC } & \multicolumn{2}{|c|}{ Material } & \multicolumn{3}{|c|}{ accuracy } & \multicolumn{3}{c|}{ completeness } \\
\hline & & Yes & Less & No & Yes & Less & No \\
\hline $\mathbf{3 . 1 3}$ & Pantun, syair, dan gurindam & $\sqrt{ }$ & & & & $\sqrt{ }$ & \\
\hline $\mathbf{4 . 1 3}$ & Pantun, syair, dan gurindam & $\sqrt{ }$ & & & & $\sqrt{ }$ & \\
\hline $\mathbf{3 . 3}$ & Official and private letters & $\sqrt{ }$ & & & $\sqrt{ }$ & & \\
\hline $\mathbf{4 . 1 2}$ & Debate & & $\sqrt{ }$ & & $\sqrt{ }$ & & \\
\hline $\mathbf{3 . 1 4}$ & Biographical text & $\sqrt{ }$ & & & $\sqrt{ }$ & & \\
\hline $\mathbf{4 . 1 5}$ & Biographical text & $\sqrt{ }$ & & & & $\sqrt{ }$ & \\
\hline $\mathbf{4 . 1 1}$ & Fabel & $\sqrt{ }$ & & & & $\sqrt{ }$ & \\
\hline $\mathbf{3 . 1 3}$ & Official and private letters & $\sqrt{ }$ & & & & $\sqrt{ }$ & \\
\hline $\mathbf{3 . 1 2}$ & Fabel & $\sqrt{ }$ & & & & $\sqrt{ }$ & \\
\hline $\mathbf{4 . 1 3}$ & Official and private letters & $\sqrt{ }$ & & & $\sqrt{ }$ & & \\
\hline
\end{tabular}

The data in the form of authentic assessment is taken from Lesson implementation plan made by the teachers of Indonesian Language and Literature. The selected schools are Pakuan University partner schools using the Curriculum 2013, such as: 1) SMPN 1 Ciawi, 2) SMPN 9 Bogor, 3) SMA Negeri 9 Bogor, 4) SMPN 
2 Bogor, and 5) SMAN 10 Bogor.Here's a table of accuracy and completeness between evaluation instrument and $\mathrm{BC}$

Of the 11 BCs examined from the table above, $10 \mathrm{BC}$ or $90.9 \%$ evaluation instrument are made and $1 \mathrm{BC}$ or $9.1 \%$ is not made. This allows the lack of students understanding of the $\mathrm{BC}$.

Seen from the table above, the appropriate evaluation instrument is in accordance with BC 9 or 90\%; while the evaluation instrument is less precise, less appropriate with BC as much as 1 or by $10 \%$. Complete evaluation instruments are 4 or $40 \%$ and incomplete evaluation instruments are 6 or $60 \%$.

There are 7 authentic forms of assessment, such as: performance 1, project , portfolio , written , attitude , self, and product assessments.

Here is the table of authentic assessment forms used by the teachers studied

\begin{tabular}{|c|c|c|c|c|c|c|}
\hline \multirow[b]{2}{*}{ BC } & \multicolumn{6}{|c|}{ Autentic Assesment Form } \\
\hline & $\begin{array}{c}\text { Performa } \\
\text { nce }\end{array}$ & Project & Portofolio & Written & Attotude & Self \\
\hline 3.13 & & & & $\sqrt{ }$ & & \\
\hline 4.13 & & & & $\sqrt{ }$ & & \\
\hline 3.3 & & & & $\sqrt{ }$ & & \\
\hline 4.12 & & & & $\sqrt{ }$ & & \\
\hline 3.14 & & & & $\sqrt{ }$ & & \\
\hline 4.15 & $\sqrt{ }$ & & & & & \\
\hline 4.11 & & & & $\sqrt{ }$ & & \\
\hline 3.13 & & & & $\sqrt{ }$ & & \\
\hline 3.12 & $\sqrt{ }$ & & & & & \\
\hline 4.13 & & & & $\sqrt{ }$ & & \\
\hline
\end{tabular}

Based on the table above, of the $10 \mathrm{BCs}$ devised by the assessment instruent, there are $2 \mathrm{BCs}$ or $20 \%$ of the total in the form of performance appraisals, the type is the act / practice orally; and $8 \mathrm{BC}$ or $80 \%$ written assessment, in the form of multiple choice test and description (short field and essay).

\section{Data}

\section{5: Lesson Plan Appraisal}

\begin{tabular}{|c|c|c|c|}
\hline No & BC & Indicator & Purpose \\
\hline 3 & $\begin{array}{l}4.15 \\
\text { Constructing } \\
\text { biographical } \\
\text { text of a figure }\end{array}$ & $\begin{array}{l}\text { 4.15 } \\
\text { 1. Identify biographical } \\
\text { texts of aspects of } \\
\text { meaning, structure, and } \\
\text { language } \\
\text { 2. Apply the structure of } \\
\text { the biographical text } \\
\text { orally } \\
\text { 3. Discover the main idea } \\
\text { of the biographical text } \\
\text { 4. Presents the central } \\
\text { idea of biographical texts } \\
\text { 5. Draw biographical text } \\
\text { of inspirational figures } \\
\text { 6. Demonstrate the } \\
\text { contents of biographical } \\
\text { texts with different } \\
\text { presentation patterns }\end{array}$ & $\begin{array}{l}\text { 1. Identify biographical } \\
\text { texts of appropriate } \\
\text { aspects of meaning, } \\
\text { structure, and linguistics } \\
\text { 2. Orally demonstrate } \\
\text { the three structures of } \\
\text { the biographical text } \\
\text { orally } \\
\text { 3. Find the basic ideas } \\
\text { of the biographical texts } \\
\text { appropriately } \\
\text { 4. Promulgates the basic } \\
\text { idea of the biographical } \\
\text { text properly and } \\
\text { correctly } \\
\text { 5. Prepare biographical } \\
\text { texts of inspirational } \\
\text { figures by looking at } \\
\text { aspects of content, } \\
\text { structure, and linguistics } \\
6 . \text { Demonstrate the } \\
\text { contents of biographical } \\
\text { texts with different } \\
\text { presentation patterns } \\
\text { properly and correctly }\end{array}$ \\
\hline
\end{tabular}

\section{Evaluation}

\begin{tabular}{|c|c|c|c|c|c|c|}
\hline No. & $\begin{array}{c}\text { Name of } \\
\text { Instrument }\end{array}$ & $\begin{array}{c}\text { Sort of } \\
\text { Instrument }\end{array}$ & $\begin{array}{c}\text { Sort } \\
\text { of } \\
\text { Test }\end{array}$ & Test Items & $\begin{array}{c}\text { Accurac } \\
\mathbf{y}\end{array}$ & $\begin{array}{l}\text { Compl } \\
\text { eteness }\end{array}$ \\
\hline 1 & $\begin{array}{l}\text { Penilaian } \\
\text { keterampil } \\
\text { an } \\
\text { KD } 4.15 \\
\text { Indikator } \\
4.15 .1 \\
4.15 .2 \\
4.15 .3 \\
4.15 .4 \\
4.15 .5 \\
4.15 .6 \\
\text { Tujuan 1, } \\
2,3,4,5 \text {, } \\
\text { dan } 6\end{array}$ & Lisan & Lisan & $\begin{array}{l}\text { 1. Identify biographical } \\
\text { texts according to } \\
\text { predetermined } \\
\text { biographical figures } \\
\text { from aspects of } \\
\text { meaning, structure, } \\
\text { and language! } \\
\text { 2. Show repeat stories } \\
\text { of biographical texts } \\
\text { of which sections } \\
\text { include orientation, } \\
\text { important events, and } \\
\text { reorientation! } \\
\text { 3. Find the ultimate } \\
\text { idea of the } \\
\text { biographical text } \\
\text { your group possesses } \\
\text { appropriately! } \\
\text { 4. Clarify the main } \\
\text { ideas found from the } \\
\text { biographical texts } \\
\text { well and correctly } \\
\text { orally using their } \\
\text { own language! } \\
\text { 5. Arrange biographical } \\
\text { text of inspirational } \\
\text { figures by looking at } \\
\text { aspects of content, } \\
\text { structure, and } \\
\text { language! } \\
\text { 6. Demonstrate the } \\
\text { contents of } \\
\text { biographical texts } \\
\text { with different } \\
\text { presentation patterns } \\
\text { properly and } \\
\text { correctly! }\end{array}$ & $\begin{array}{l}\text { It is } \\
\text { exactly } \\
\text { in } \\
\text { accordan } \\
\text { ce with } \\
\mathrm{KD}, \\
\text { indicator } \\
\mathrm{s} \text {, and } \\
\text { goals. } \\
\text { However } \\
\text { question } \\
2 \text { of the } \\
\text { good is } \\
\text { no } \\
\text { empirica } \\
1 \\
\text { evidence } \\
\text { found in } \\
\text { the } \\
\text { biograph } \\
\text { ical text }\end{array}$ & $\begin{array}{l}\text { Incomp } \\
\text { lete, } \\
\text { there } \\
\text { are } \\
\text { only } \\
\text { questio } \\
\text { ns, } \\
\text { answer } \\
\text { keys, } \\
\text { and } \\
\text { assess } \\
\text { ment } \\
\text { rubrics, } \\
\text { no } \\
\text { scoring } \\
\text { guideli } \\
\text { nes }\end{array}$ \\
\hline
\end{tabular}

\section{Performance Appraisal Assesment}

\begin{tabular}{|c|l|c|c|}
\hline No. & \multicolumn{1}{|c|}{ Criteria } & $\begin{array}{c}\text { Yes } \\
\text { (2) }\end{array}$ & $\begin{array}{c}\text { No } \\
\text { (1) }\end{array}$ \\
\hline 1 & Obviously in conveying the contents of biographical texts & & \\
\hline 2 & Sync between things verbally told with biographical texts & & \\
\hline 3 & Clarity of pronunciation & & \\
\hline 4 & Voice clarity & & \\
\hline 5 & Using language that is easily understood by the listener & & \\
\hline 6 & Vocal chords when telling the contents of biographical texts & & \\
\hline 7 & Confident in the show & & \\
\hline 8 & $\begin{array}{l}\text { Able to use his own sentences in conveying the contents of } \\
\text { biographical texts }\end{array}$ & \\
\hline
\end{tabular}

Basic competence 4.15 Preparing biographical text of the figures, the formulated indicators are: 1) Identifying biographical texts of aspects of meaning, structure, and language, 2) Demonstrate the structure of biographical text orally, 3) Finding key ideas from biographical texts, 4) from biographical texts, 5) Prepare biographical texts of inspirational figures, 6) Demonstrate the contents of biographical texts with different presentation patterns. The indicators are formulated in the following learning objectives. 1) Identify biographical texts of the appropriate aspects of meaning, structure, and language, 2) Demonstrate the three structures of biographical text orally correctly, 3) Find key ideas of biographical texts appropriately, 4) Brainstorm the main ideas of biographical texts well true, 5) Prepare biographical text of inspirational 
figures by looking at aspects of content, structure, and language, and 6). Demonstrate the contents of biographical texts with different presentation patterns properly and correctly.

Six indicators are developed from basic competencies which are then formulated with six goals and indicators. However, closely looking at the indicator 2, we see that the main idea of biographical texts can be combined between 3 and 4 .

Oral test assessment is conducted in the form of demonstrating activities. Which is also presented in a rubric assessment.

Based on the results of research on authentic assessment of the Learning Implementation Plan in various secondary schools in the city of Bogor (PPL partners) disclosed things as follows.

1. The developed basic competencies have been described in the indicators. The development of indicators is in line with the basic competencies. But there is still a lack of conformity in the development of indicators. The lack of conformity is a) the inaccuracy in selecting operational verbs and b) there is still insufficient development of indicators.

2. The formulation of teacher's objectives has been referring to the formulation of indicators. But there is still a mistake in the formulation of goals that should follow the formulation of the learning objectives, such as not presenting aspects of condition (condition) and degree (level). And several formulation of goals still use unoperational verbs.

3. In the preparation of authentic assessment, it can be disclosed that authentic assessment is designed in accordance with the objectives of learning. But we still found the incompleteness of the instrument, a key answer. The types of questions that are generally selected are descriptions (short stuff and essays), very few multiple choice questions are applied.

\section{CONCLUSION}

Understanding of KD, indicators, and learning objectives is very important in preparing the Lesson Plans. So is the understanding of authentic judgments. Teachers need to look at the development of indicators, the formulation of appropriate goals and the development of relevant issues as well. Completeness of the problem instrument needs to get attention, especially in composing the key answers, as the signs in conducting the assessment.

\section{REFERENCES}

Kementerian Pendidikan dan Kebudayaan. 2013. Diklat guru dalam rangka implementasi kurikulum 2013. Jakarta: Kemendikbud.

Kementerian Pendidikan dan Kebudayaan. 2012. Rambu-rambu pelaksanaan PLPG. Jakarta: Kemendikbud.
Kunandar. 2013. Penilaian autentik (penilaian hasil belajar peserta didik berdasarkan kurikulum 2013). Jakrta: PT Raja Grafindo Persada.

Mahsun. 2014. Teks dalam pembelajaran bahasa indonesia kurikulum 2013. Jakarta: Raja Grafindo Persada.

Majid, A. 2014. Strategi pembelajaran. Bandung: Remaja Rosdakarya.

Moleong, L. 1989. Metodologi penelitian kualitatif. Bandung: Remaja Karya.

Nurgiyantoro, B. 2001. Penilaian dalam pengajaran bahasa dan sastra. Yogyakarta: BPFE.

Nurkancana, W. dan Sumartana. 1986. Evaluasi pendidikan. Surabaya: Usaha Nasional. 